\title{
Judicial Review of Ministerial Advice to the Crown
}

\author{
Mark D Walters ${ }^{\star}$
}

For Thomas Hobbes, nothing illustrated the "inconstant use of words" better than the confusion between "Counsels and Commands," for the words "Doe this," he said, "are the words not only of him that Commandeth; but also of him that giveth Counsell." ${ }^{1}$ This confusion remains with us today. We still do not have a sound grasp of the distinctive place that counsel or advice plays within our constitutional system. How is ministerial advice to the sovereign concerning how a power ought to be exercised different from the exercise of the power itself? Does ministerial advice exist within a domain of political action beyond the reach of law? These are persistent questions in Canada.

Consider Aniz Alani's challenge to the decision made in 2014 by (then) Prime Minister Stephen Harper to stop filling Senate vacancies - or, to speak more accurately, the decision to refuse to advise the Governor General of Canada to fill Senate vacancies. ${ }^{2}$ The challenge survived several preliminary rounds before being dismissed as moot (since the present Prime Minister has begun to fill Senate vacancies). ${ }^{3}$ Alani pressed on with his case and government lawyers continued to fight for good reason. ${ }^{3}$ The challenge was about more than just Senate vacancies. It was really a case about executive power and the rule of law. The question that the case raised is whether assertions of executive power by prime ministers (or other ministers) in the form of advice or counsel to the Crown are shielded from judicial review because they occupy a world of politics outside the bounds of law.
The orthodox view is that the Crown or its representative in Canada must exercise its legal powers only upon the advice of ministers who are responsible to the elected members of Parliament, and that this rule is one of constitutional convention, not law. ${ }^{4}$ Rules of constitutional convention are, in the orthodox view, customary rules of constitutional practice or morality enforced politically, whereas rules of constitutional law are true laws enforced by courts. ${ }^{5}$ Applying these ideas, the government argued that Alani's case had to fail: the Prime Minister's "advisory role" in Senate appointments "exists only by virtue of the constitutional convention" and so it cannot be a concern for judges. ${ }^{6}$ Prime ministerial advice to the Crown is, in other words, sealed off from law. Was this argument sound? Does constitutional convention allow executive power asserted in the form of advice or counsel to reign within a "legal black hole"?7 Although the case was dismissed for mootness, the substance of the arguments it raised are worth considering.

To answer the questions raised, we need a more complete understanding of the legal status of ministerial advice to the Crown. This is not a topic that has attracted much attention in Canada. In our constitutional tradition, the most fundamental aspects of governance evolve implicitly and questions about the legality of political action are often left unaddressed until, that is, someone in power begins to behave in a manner that cuts against the grain of settled constitutional assumptions. At these moments, there is an understandable desire to shine legal light into areas of constitutional life that have 
been obscured in darkness. The world of ministerial advice is one such area. However, the task of building a legal account of ministerial advice need not involve radical steps. On the contrary, it is best if it proceeds in the ordinary common law way, one that looks back to the principles that have shaped the emergence of legality within our system. In this essay, I will offer the outlines of such an account. I will suggest that the government's position in the Alani case was based upon a non sequitur. It is true that in relation to many of its powers the Crown follows ministerial advice by virtue of extra-legal convention. However, it does not follow from this proposition that ministerial advice has no legal foundation or is left wholly undisciplined by law.

Before explaining this argument, a few preliminary comments are necessary. First, in developing a legal theory of ministerial advice to the Crown in this essay, I will focus on the federal sphere and I will take "Crown" loosely to mean the Queen or the Governor General when exercising legal powers pursuant to either the royal prerogative or a specific written provision of the Constitution of Canada.

Second, I will argue that there are circumstances in which the legality of ministerial advice to the Crown to make a decision may, independently of the resulting decision itself, be open to judicial scrutiny. Of course, if the goal is to challenge the legality of a Crown decision, it will usually be necessary to seek judicial review of that decision rather than the advice that produced it. ${ }^{8}$ Still, the conduct of ministers as advisors may become legally relevant in a number of situations. For example, the legality of the decision may hinge upon the legality of the advice that produced it; or, the problem may be (as in the case of Alani) a minister's refusal to give advice so that there is no Crown decision to attack; or, finally, there may be situations in which no point would be served by having a particular Crown decision quashed on judicial review and yet there are legitimate reasons to seek a judicial declaration to the effect that the minister who advised the Crown to make the decision was wrong in law to have done so. In discussing the judicial review of ministerial advice to the Crown, I have any and all of these possibilities in mind.

Third, it should be acknowledged that many Crown decisions involve politically sensitive matters that affect the public broadly. Questions will therefore arise as to who has standing to challenge these decisions in court. ${ }^{9}$ Questions will also arise, especially in relation to decisions of so-called "high policy" made pursuant to the royal prerogative, about whether the matter is even justiciable. ${ }^{10}$ For the purposes of this essay, I will bracket these questions and leave them to the side. My concern is not with the judicial review of Crown decisions as such, but with judicial review of the ministerial advice governing how those decisions are made. I want to challenge the notion that ministerial advice is a matter of convention only and is unreviewable by judges for that reason. But I concede that even if I am right and this notion is rejected, rules about standing and justiciability may still block the judicial review of at least some kinds of ministerial advice, for the same reasons that these rules may limit the ability to challenge certain kinds of Crown decision.

Finally, it is important to distinguish between decisions made by the Governor General based on ministerial advice and decisions of the Governor in Council. Where the Governor General is given power by the Constitution Act, 1867, it is usually a power conferred upon the "Governor General" alone. However, in a few instances power is conferred upon the "Governor General in Council," in which case the power must be exercised by the Governor General "acting by and with the Advice of the Queen's Privy Council for Canada" (s. 13). This is true also where an ordinary statute confers a power upon the "Governor in Council." ${ }^{11}$ The Privy Council for Canada is established by section 11 of the Constitution Act, 1867 and consists of all present and former ministers of the Crown as well as a variety of other members. Although it is only by virtue of convention that the legal powers conferred upon the "Governor in Council" are exercised by the Governor and present cabinet ministers, it is by virtue of law that these ministers, sitting as a committee of the Privy Council, participate 
with the Governor to make the decision. In these circumstances, ministers are not merely advising the Governor as to what he or she should decide; they are, as a matter of law, joining with the Governor to make the decision. ${ }^{12}$ So, the judicial review of decisions made pursuant to a constitutional or statutory delegation of authority to the "Governor in Council" falls outside the scope of this essay. The focus of my inquiry is advice by ministers who do not have the legal power to make a decision (or to participate in the making of a decision) given to the person who does have the legal power to make the decision.

\section{Command versus counsel}

Sir William Blackstone's account of the British constitution was criticized by A.V. Dicey for its failure to recognize the practical realities of how the King and his advisors actually behave. ${ }^{13}$ In the Blackstonian account, the King really does exercise the tremendous power ascribed to him by law, and his ministers really are just advisors. However, constitutional rules of a customary or conventional nature had of course, even by Blackstone's time, and certainly by Dicey's, served effectively to reverse the power relationship defined by law. Rather than ministers submitting advice for royal consideration, it was more accurate to say, as Walter Bagehot did, that the Crown had at most "the right to be consulted [by], the right to encourage, [and] the right to warn" his or her ministers. ${ }^{14}$ Ministers, not the Crown, came to wield the power of decision.

And yet when the suggestion is made in Canada today that ministerial advice to the Crown might be legally challenged, the formal legal rules spring back into life in all of their Blackstonian glory. It will be said in response to the suggestion, as the government said in the Alani case, that the Crown has the legal authority to act and the minister's role is only to advise, and it will be added, with emphasis, that the advice is given as a matter of constitutional convention only and so cannot be the subject of judicial review. In this way, executive power may be exercised in a legal black hole.
One way to address this worrisome conclusion is to question the assumption that constitutional conventions are never justiciable. Perhaps the time has come to contemplate the possibility of at least declaratory judicial relief when ministerial advice flouts established conventional rules. In this way, the veil of law would be pierced to reveal where real power lies. However, there is another response that may at first appear counterintuitive. This second approach accepts the orthodox line drawn between law and convention, but insists that if the minister is to rely upon strict law and say that his or her involvement in the impugned decision was purely a matter of non-binding advice, then it becomes appropriate for the courts to apply the law regarding ministerial advice strictly as well. The various constitutional conventions governing how and when advice is given are here left to the side. Instead, the focus is on the legal character of ministerial advice to the Crown. In this essay, I will pursue this second line of reasoning.

Once we are in the world of strict or formal law, a world in which the Crown has the power and the minister is mere advisor, we must ask ourselves what, as a matter of formal law, being an advisor really means. In answering this question, it may be helpful to return to where we started - the work of Thomas Hobbes. In his masterpiece, Leviathan, Hobbes argues that civil or positive law is the command of the sovereign. Before explaining this point, however, Hobbes discusses the distinction between command and counsel. ${ }^{15} \mathrm{He}$ observes that command "is where a man saith, do this, or do not this, without expecting other reason than the will of him that says it ... for the reason of his command is his own will only." In contrast, counsel "is where a man saith, do, or do not this, and deduceth his reasons from the benefit that arriveth by it to him to whom he saith it", and he that gives the counsel "pretendeth only ... the good of him to whom he giveth it." One who commands might claim a right to do so, as a sovereign would, but, Hobbes argues, no one "can pretend a right" to be counsel to someone else.

For Hobbes, then, two significant features distinguish command from counsel. First, a 
commander can claim authority over the commanded, insisting upon a right to force compliance with the command, whereas a counselor can never claim authority over the counseled or even a right to give counsel. Second, the command itself, rather than the substantive reasons that prompt it, provides the reason for those subject to the command to act in the manner commanded, whereas the reason to act in accordance with counsel cannot be separated from the substantive reasons offered in its support. These points are similar to the account of authority developed by Joseph Raz. ${ }^{16}$ Restating Hobbes' points in Razian terms, we would say that counsel is advice given by one person to another on how they ought to act in a given situation based upon the advisor's weighing of the first-order reasons for action relevant for the person in that situation. The person to whom counsel is given must still engage in some kind of independent weighing of the relevant reasons for action before deciding what to do, but in doing so they may be influenced by or may even adopt the assessment of the reasons for action offered by the advisor. A command, in contrast, is a form of second-order reason for action that, for those subject to the command, excludes from their consideration all of the firstorder reasons for action that otherwise would have governed their assessment of what to do in the situation. On this view, one follows counsel offered because one accepts the substantive reasons justifying the advised course of action, but one follows a rule that is commanded for the sole reason that it has been commanded. It follows that if one were to make it a practice to follow the advice of a certain person on certain matters without any independent assessment of the firstorder reasons for that advice, then the advice or counsel would become, in effect, a form of rule and the person would have accepted the advisor as a commander having authority over them.

To this skeletal conception of counsel, Hobbes offers several more points relevant to the advisors of the sovereign. First, he argues that "counseling" requires "great knowledge of the disposition of mankind, of the rights of government, and of the nature of equity, law, justice, and honour." Second, he insists that ministers offering counsel to the sovereign should not be punished for giving advice conflicting with the opinions of either the sovereign or the people, for counsel is always given as part of a sincere "debate" about what to do. However, Hobbes adds an important qualification: a minister is punishable for advice "contrary to the laws, whether that counsel proceed from evil intention or from ignorance only." To counsel the sovereign to change the law is one thing, but to counsel the sovereign to act against the law without first changing it is a completely different thing. The former falls within the legitimate domain of ministerial counsel, whereas the latter does not.

I do not mean to advance a positivist view of law and constitutionalism of the kind associated with the work of either Hobbes or Raz. ${ }^{17}$ However, the Hobbes-Raz account of counsel or advice does help us to see, I think, the outlines of a conception of ministerial advice to the sovereign. In this account, advice-giving emerges as a duty to provide substantive but non-binding reasons for action, and this duty arises from and is conditioned by law. Of course, this is not an accurate description of the relationship between ministers and the Crown in Canada that has emerged by convention; but it is, I argue, an accurate description of their position as a matter of formal law.

\section{The King's privy council}

The outlines of the legal theory of ministerial advice sketched above finds support within the common law. According to Sir Edward Coke, the advisors who together came to be known as the King's privy council were required to act "like good centinels and watchmen" capable of advising the Crown as to "the publique good." ${ }^{8}$ For Coke, "good counsel" was "the soul of the state." ${ }^{19}$ A century and a half later, Blackstone relied upon Coke in explaining the position of the King's ministers: it was to "assist" the King in maintaining his dignity and prerogative that "the law hath assigned him a diversity of councils to advise with," the "principal" one being "his privy council, which is generally called, by way of eminence, the council." 20 
The privy council was, as Blackstone insisted, established by law to provide the Crown with advice. It evolved from the ancient curia regis to which the King's tenants-in-chief were summoned to provide counsel. ${ }^{21}$ Tenants generally were required, as one of the duties they owed to their lord, to attend the lord's manorial court to give counsel, the lord's right to hold a court of his tenants for this purpose being, by the common law, an "incident to the manor." ${ }^{22}$ The right of the medieval King as lord paramount to summon his tenants-in-chief to the curia regis may be seen as this legal right writ large. ${ }^{23}$ The "interchange of advice" was something demanded by the King from nobles as a show of submission and allegiance. ${ }^{24}$ It was thus the Crown's prerogative or common law right to summon advisors to gather in council. It follows that the act of attending upon the sovereign to give advice in the privy council could not itself have been a power or a right; it was, on the contrary, a common law duty owed to the sovereign by those summoned. ${ }^{25}$ Indeed, to refuse to assist the King "in his councils, by advice, if called upon," constituted misprision, a criminal offence involving neglect of a public function or office. ${ }^{26}$

The idea that ministerial advice to the Crown is a matter unknown to and outside the law is therefore wrong. It is a misunderstanding that results from the confusion between law and convention. The privy council emerged as an inner circle of royal advisors in the sixteenth century; but even it was too large to perform daily tasks of administration, and the convention arose that the Crown would consult only a committee of the council consisting of advisors presently holding high office. Thus emerged the distinction between council and cabinet. ${ }^{27}$ With the rise of cabinet government, the existence of the council slipped into the shadows. And because the existence of a cabinet of ministers, including the prime minister, emerged through convention rather than law, it was perhaps natural for people to assume that the law knows nothing of these advisors and the advice they give. What cannot be overlooked, however, is that these advisors, the prime minister included, can only give advice to the Crown in the constitutionally relevant sense by virtue of their membership within the privy council, a body that is "very well known to the law." ${ }^{28}$ Convention, not law, compels the Crown to seek and act upon the advice of privy councillors, and convention determines which privy councillors must be consulted; however, the resulting act of advice-giving is the performance of a legal duty triggered by the advisor's membership within a council constituted by law for the very purpose of providing counsel.

In Canada, this conclusion of common law is constitutionally entrenched. The advisory role performed by ministers of the Crown arises by virtue of the membership of ministers within what is perhaps the most overlooked institution within the Canadian constitutional order, established by what is perhaps one of the most neglected provisions within the Constitution of Canada. Section 11 of the Constitution Act, 1867 provides: "There shall be a Council to aid and advise in the Government of Canada, to be styled the Queen's Privy Council for Canada; and the Persons who are to be Members of that Council shall be from Time to Time chosen and summoned by the Governor General and sworn in as Privy Councillors." That the Governor General must act on the advice of the reigning prime minister and other ministers presently serving in cabinet is a rule of constitutional convention. However, the act by the prime minister or other ministers in advising the Governor General is not conventional; it is, rather, the performance of a duty arising in constitutional law by virtue of section 11 of the Constitution Act, 1867 (and the common law constitutional principles it affirms) to 'aid and advise' in the government of Canada.

Having established that the giving of ministerial advice to the Crown is the performance of a common law duty, or, in Canada, a written constitutional law duty, the next question to ask is whether that performance is governed only by rules of constitutional convention or whether it is also informed and constrained by law.

\section{The King can do no wrong - but his ministers can}

The rule that the Crown must act upon ministerial advice may be a rule of constitutional con- 
vention rather than law - but it is not ignored by law. On the contrary, it lies at the heart of the common law's understanding of legality. It was long recognized by the common law that by virtue of the royal prerogative the King can do no wrong. This principle embraced a series of ideas historically, including the Crown's immunity from suit and the Crown's inability to commit an unlawful or an illegal act. There are three ways to understand the principle. It could be said that the King is above the law. Or, it could be said that whatever the King does is by definition consistent with the law. Or, finally, it could be said that whenever the King commits an act that is unlawful, someone else must have been responsible and legal remedies must be sought against them rather than the King. This third explanation was adopted by the common law and it was critical to the emergence of what would become known as the rule of law. Of course, the obvious candidates for those responsible for misguiding the King were his ministerial advisors.

Once again, however, conventions obscure legal realities. The important conventions surrounding ministerial responsibility to Parliament have distracted our attention from other ways in which ministers may be held responsible for their conduct. "[W] hen we speak of ministerial responsibility we too often think merely of the socalled responsibility of ministers to Parliament," Frederick Maitland says, but "[s]trictly speaking" ministers are not responsible to Parliament, for neither House has the legal power to dismiss a minister; rather "in all strictness the ministers are responsible before ... the ordinary courts of law." ${ }^{29}$ William Anson makes a similar point. The maxim "the King can do no wrong" means, first, that ministers advising the King become responsible to Parliament for "mistakes of policy", and, second, that "the King is not responsible when he acts on the advice of his Ministers even though the action thus taken is contrary to law." ${ }^{30}$ In this latter respect, Anson writes:

[T] he King is not above the law ... He summons, prorogues, and dissolves Parliament; appoints to all the great executive, judicial, and spiritual offices; makes peace, war, and treaties; confers dignities, grants charters, authorizes the spending of public money, sets in motion the judicial circuits: for these and any other acts which the King must do in his official capacity some one is responsible, and if the law is broken legal responsibility attaches to the lawbreaker. ${ }^{31}$

Who is the law-breaker when the Crown acts unlawfully? Public officials who execute or implement unlawful Crown decisions are at common law legally responsible. But what about those who advise an unlawful course of action? "[A]s the King cannot misuse his power, without the advice of evil counselors," Blackstone wrote, "these men may be examined and punished," for "no man shall dare to assist the Crown in contradiction to the laws of the land." 32 The renowned Admiralty court judge, Sir William Scott, observed that should "the Crown" violate the law in an emergency the solution would be an Act of Indemnity passed by Parliament absolving from legal responsibility, first, "those who advise[d]" the Crown to make the unlawful decision, and, second, "those who carr[ied] it into execution." ${ }^{3}$ "If any person advise the King to do any illegal act," wrote William Hearn, "he is guilty of a misprision, no less than if he had assisted in the commission of the act itself. The evil counsellor needs not be concerned in the execution of his project. The advice and the execution are two distinct offences." ${ }^{34}$ Hearn is referring here to the offence of positive misprision, or "maladministration of such high officers, as are in public trust and employment." 35

Sometimes advice will be unlawful because it produces an unlawful decision by the Crown. However, it is possible that the decision itself would not be unlawful but for the character of the advice. An example would be advice tainted by fraud or dishonesty. "A minister trusted by the King to recommend fit persons to offices," said Lord Mansfield, "would betray that trust ... if he should secretly take a bribe for that recommendation," and in such a case even a "Privy Counsellor" would be "guilty of a crime." ${ }^{36}$ Said Lord Brougham, if a "minister ... prostituted the honours of the peerage" by accepting favours in return for advising appointments to the House of Lords, the courts would "punish the offence." ${ }^{37}$ 
A minister might also face civil liability for advice given to the Crown. Consider Dickson $v$ Viscount Combermere, an action for damages against the Secretary of State for War for falsely and maliciously advising the Queen to dismiss the plaintiff from the office of Lieutenant-Colonel in the militia. ${ }^{38}$ The editors of the report of this case were, in a footnote, incredulous: the dismissal was an act of the "prerogative" and the Secretary of State should be "protected from all liability" for acts done "by way of advice to the Sovereign as Cabinet Minister." ${ }^{39}$ And yet Lord Chief Justice Cockburn was in no doubt that an action could lie against a minister for acting maliciously when advising the Crown, stating that the question before the court was not whether the Secretary of State "discharged his duty wisely," a point upon which "he is responsible to his Sovereign and the country," but whether "he has dishonestly and corruptly abused the power intrusted to him," in which case the jury could "find a verdict against him." 40

Ministerial advice to the Crown, though triggered by convention, is given in the performance of a legal duty by ministers who hold a legal office, and the common law has always regarded ministers as legally responsible for the advice they give. Ministerial advice does not operate within a legal black hole. Of course, the old authorities I have cited on this point contemplate either a criminal prosecution or an action in tort, with examples of fraud, corruption, malicious abuse of public office, or flagrant neglect of public duties being given. I am not suggesting that the law historically acknowledged a modern remedy of judicial review of ministerial advice based upon public law principles of rationality, legality and fairness. I do think, however, that once the domain of ministerial advice is understood to be one governed by law, the forms of law that discipline advice must be understood in the usual legal way as expanding with the incremental developments that have shaped modern public law generally. As we move into the twentieth century, we can see that this basic line of argument has, in effect, been accepted in the United Kingdom.

\section{Bentley's case}

The 1994 case of R. v. Secretary of State for the Home Department, ex p. Bentley involved an application for judicial review of a decision by the British Secretary of State for the Home Department refusing a posthumous free pardon for Derek Bentley, who had been convicted of murder and executed in the 1950s. ${ }^{41}$ It was argued that the decision by the Home Secretary was based upon an error of law concerning the nature of a free pardon and that it was perverse in light of the fundamental interests at stake. For our purposes, what is important about the case is the character of the decision that was judicially reviewed.

First, we should recall that the act of pardoning is an exercise of the royal prerogative of mercy. Second, it is clear that in this case the decision to refuse mercy was, in fact, made by the Home Secretary. Third, as a matter of law, however, the Home Secretary was not exercising the prerogative of mercy himself but was deciding whether or not to advise the Crown to exercise the prerogative of mercy. In other words, this case involved the judicial review of a decision by a minister of the Crown refusing to advise the Crown to exercise one of its legal powers, advice that would have been binding only by virtue of convention, not law. In this respect, Bentley is the same as the case of Alani involving the judicial review of the Prime Minister's decision to refuse to advise the appointment of Senators. However, unlike in Alani, in Bentley counsel did not argue that the minister's advice-giving role was a matter of convention only and therefore beyond the reach of law. In the end, the judges assumed that because the prerogative of mercy is itself justiciable, the Home Secretary's advice as to its use is as well.

Two observations can be made about Bentley. First, the applicant in Bentley did not seek to enforce a convention through judicial review. The gist of the claim, which was accepted by the court, was that in giving advice as to how the prerogative ought to be exercised, advice that was by convention binding on the Crown, the minister was bound by public law standards of legality 
and rationality that inform executive decisionmaking generally. Second, the court considered carefully the reasons given by the minister for the advice, or rather the decision not to advise. The reasons fell short of the public law standard of rationality in the exercise of discretion because they were based upon a misunderstanding of the law relating to pardons and because they failed to weigh sufficiently the fundamental human interests, or constitutional values, implicated by applications for mercy. This point takes us back to the theoretical framework for understanding advice or counsel as a legal idea that I sketched above. In law, counsel can never be a simple command; rather, its normative force must derive from the first-order reasons for action offered by the advisor to the sovereign. These reasons are not binding in law, of course, but they are necessary if the advice is to have meaningful substance as counsel for the sovereign. As a matter of law, advice must be based upon reasoned justifications. The point of judicial review of ministerial advice, in my view, is to address those cases where the reasoned justifications offered for how the advicegiving duty is performed fail to incorporate due regard for basic principles or values within constitutional law that shape the constitutional structure as a whole.

\section{Ministerial advice and Canadian constitutional structure}

We may close this discussion by returning to the Alani case. Alani brought into relief the question of whether ministerial decisions that have a profound impact upon the constitutional order are, due to their formal status as advice or counsel, made in a field of political action that lies outside the law. Looking back to the old cases, one thing is clear: ministerial advice concerning appointments to the upper chamber of Parliament in the United Kingdom is subject to law and judicial supervision, at least when claims of fraud or dishonesty are made. Surely ministerial advice relating to the upper chamber of the Canadian Parliament is similarly bound by law. But can we say that ministerial advice to the Crown is also reviewable on other public law grounds? Is there any reason why the approach taken in Bentley is inappropriate in Canada?

Ministers exercising discretionary powers pursuant to an ordinary statute are bound by law to respect the basic constitutional values that define the structure of the Constitution of Canada. ${ }^{42}$ When the exercise of ministerial discretion under a statute affects constitutional values, it must be shown that the minister gave due regard to those values so that the decision may be justified as a reasoned and proportionate balancing of relevant values with other legitimate objectives. ${ }^{43}$ Once it is determined that ministerial advice to the Crown is the performance of a legal duty imposed by a written provision within the Constitution of Canada, there seems to be no good reason to resist the extension of these principles to the conduct of ministers in giving advice. The objective would not be the judicial enforcement of the constitutional conventions that guide political behaviour in this area. The objective, rather, would be to ensure that a legal duty prescribed by the Constitution of Canada "to aid and advise in the Government of Canada" is performed consistently with the Constitution of Canada. Not all ministerial advice will be judicially reviewable, simply because not all advice gives rise to points of law susceptible to judicial interpretation.

However, if, as I have argued in this essay, ministerial advice is, in law, counsel based upon an assessment of first-order reasons for action, then at least in those cases where the reasons for advice are publicly given or can otherwise be established through evidence (I leave to the side for now whether there might be a legal duty on ministers to provide reasons for the advice they give), the question of whether those reasons are consistent with constitutional values and structure may well be, in the appropriate circumstances, a question of law for the courts to determine. In fact, judicial review of ministerial advice to the Crown will rarely occur. But the mere acknowledgement that it might occur is, I think, important. For a culture of legality to flourish, political actors must have the sense that everything they do must be capable of reasoned justification according to law. 
Having been told by the Supreme Court of Canada that his government's legislative proposal to reform the Senate would represent an unconstitutional attack upon the structure of the Canadian constitution, ${ }^{44}$ the Prime Minister's response, that he would simply stop making Senate appointments, bears all of the appearances of a decision made for reasons inconsistent with the structural integrity of the constitution and with the legal duties imposed upon privy councillors by section 11 of the Constitution Act, 1867 to "aid and advise in the Government of Canada." Whether this claim could have been made out in court is a question beyond the scope of this essay. However, we can at least say that the argument advanced by the government in response to Alani's claim, that ministerial advice is given pursuant to convention, not law, and so can never be judicially reviewed, must be rejected.

\section{Endnotes}

* F.R. Scott Professor of Public and Constitutional Law, McGill University.

1 Thomas Hobbes, Leviathan, or the Matter, Forme and Power of a Commonwealth Ecclesiasticall and Civil [1651] (Oxford: Basil Blackwell, 1946), chap $\mathrm{xxv}$ generally.

2 The Governor General has the power to appoint members of the Senate and to fill vacancies: Constitution Act, 1867, 30 \& 31 Victoria, c 3 (U.K.), ss 24,32 .

3 Alaniv Canada (Prime Minister), 2015 FC 649, aff'd 2016 FCA 22; Alani v Canada (Prime Minister), 2016 FC 1139.

4 Reference re Resolution to amend the Constitution, [1981] 1 SCR 753, 878-883, 125 DLR (3d) 1.

5 AV Dicey, Introduction to the Study of the Law of the Constitution, 8th ed (London: Macmillan \& Co., 1915), 413.

6 Alani v Canada (Prime Minister), Appellants' Memorandum of Fact and Law, submitted to the Federal Court of Appeal, 28 July 2015, Court File No: A-265-15, paras 24, 39, 54. This and other submissions in the case are posted at www.anizalani.com/senatevacancies/.

7 I borrow this expression from Johan Steyn, "Guantanamo Bay: The Legal Black Hole" (2004) 53 ICLQ 1-15.
8 See, for e.g., Conacher $v$ Canada (Prime Minister), 2010 FCA 131, in which Stratas JA observed at para 11 that one problem with the attempt to seek judicial review of the Prime Minister's decision to advise the Governor General to call an election was that, in the end, "it was the Governor General that called the election, not the Prime Minister."

9 It should be noted, however, that the rules on public interest standing in Canada are relatively flexible: Canada (Attorney General) v Downtown Eastside Sex Workers, 2012 SCC 45.

10 Although Black $v$ Canada (Prime Minister) (2001), 54 OR (3d) 215 (CA), following Council of Civil Service Unions $v$ Minister for the Civil Service, [1985] AC 374 (HL), held that high policy prerogative decisions are non-justiciable, there is some evidence that the law is evolving on this point and that the prerogative will be treated like statutory powers and policy concerns will be addressed through an appropriately deferential standard of judicial review rather than as a reason for barring judicial review: $R$ (Bancoult) $v$ Secretary of State for Foreign and Commonwealth Affairs, [2009] 1 AC 453 (HL); Hupacasath First Nation v Canada, 2015 FCA 4, paras 59-70.

11 Interpretation Act, RSC 1985, c I-21, ss 18(2) and 35.

12 See for e.g., Lewis v Attorney-General of Jamaica [2001] 2 AC 50 (JCPC) at 74 (re: similar provisions in the Constitution of Jamaica).

13 Dicey, supra note 5 at 7-11.

14 Walter Bagehot, The English Constitution (London: Chapman and Hall, 1867), 103.

15 Hobbes, supra note 1 at chap. Xxv (the quotations that follow are from this chapter of Leviathan).

16 Joseph Raz, Practical Reason and Norms (Oxford: Oxford University Press, 1999).

17 Indeed, Ifall on the anti-positivist side of this debate: Mark D Walters, "The Unwritten Constitution as a Legal Concept" in David Dyzenhaus and Malcolm Thorburn (eds), The Philosophical Foundations of Constitutional Law (Oxford: Oxford University Press, 2016).

18 Sir Edward Coke, The Fourth Part of the Institutes of the Law of England, Concerning the Jurisdiction of Courts (London: Printed for E and R Brooke, 1797) 53.

$19 \mathrm{Ibid}$ at 57.

20 Sir William Blackstone, Commentaries on the Laws of England (Oxford: Clarendon Press, 1765-69), vol 1, 227, 229-230.

21 George Burton Adams, "The Descendants of the Curia Regis” (1907) 13 Am Hist Rev 11-15. 
22 The King $v$ Stanton (1606), Cro Jac 260 (KB); also Dominus Rex v Staverton (1606), Yelv 190, 1 Bulst $54(\mathrm{~KB})$.

23 Sir William Anson, The Law and Custom of the Constitution, 3rd ed (Oxford: Clarendon Press, 1907), vol 2, 9, 12.

24 AV Dicey, The Privy Council, 2nd ed (London: Macmillan and Co., 1887), 2-3.

25 Mark D Walters, "The Law behind the Conventions of the Constitution: Reassessing the Prorogation Debate" (2011), 5 JPPL 131-154, 144.

26 Blackstone, supra note 20 at vol 4, 122.

27 Anson, supra note 23 at volume 2, 40; Raymond Turner, "The Origin of the Cabinet Council" (1923) 38 Eng Hist Rev 171-205.

28 FW Maitland, The Constitutional History of England: A Course of Lectures Delivered
(Cambridge: Cambridge University Press, 1908), 388-389.

29 Ibid at 484.

30 Anson, supra note 23 at vol 2, 45.

31 Ibid.

32 Blackstone, supra note 20 at vol 1, 244.

33 In re the "Adams" (1811), Edw 289, at 301-302.

34 WE Hearn, The Government of England: Its Structure and its Development (London: Longmans, Green, Reader \& Dyer, 1867), 104.

35 Blackstone, supra note 20 at vol 4, 121.

36 Rex $v$ Vaughan (1769), 4 Burr 2495 (KB), at 2498, 2499-2500.

37 Egerton v Brownlow (Earl) (1853) 4 HLC 1, at 178179.

38 Dickson $v$ Viscount Combermere (1863) 3 F \& F 526 (QB).

39 Ibid at 535.

40 Ibid at 584 (here the evidence did not show maliciousness and the action was withdrawn).

$41 R v$ Secretary of State for the Home Department ex p Bentley [1994] QB 349.

42 Baker $v$ Canada (Minister of Citizenship and Immigration), [1999] 2 SCR 817 at paras 53, 56, 174 DLR (4th) 193.

43 Loyola High School v Quebec (Attorney General), 2015 SCC 12 (Abella J.)

44 Reference re Senate Reform, 2014 SCC 32 at para 26. 